\begin{tabular}{|l|l|l||}
\hline \multicolumn{2}{|c|}{ PublisherInfo } \\
\hline \hline PublisherName & $:$ & BioMed Central \\
\hline \hline PublisherLocation & $:$ & London \\
\hline \hline PublisherImprintName & $:$ & BioMed Central \\
\hline \hline
\end{tabular}

\title{
Copies are key for gene networks
}

\begin{tabular}{|l|c|l||}
\hline \multicolumn{2}{|c|}{ ArticleInfo } \\
\hline \hline ArticleID & $:$ & 4937 \\
\hline \hline ArticleDOI & $:$ & $10.1186 /$ gb-spotlight-20040415-01 \\
\hline \hline ArticleCitationID & $:$ & spotlight-20040415-01 \\
\hline \hline ArticleSequenceNumber & $:$ & 289 \\
\hline \hline ArticleCategory & $:$ & Research news \\
\hline ArticleFirstPage & $:$ & 1 \\
\hline \hline ArticleLastPage & $:$ & 3 \\
\hline \hline & & RegistrationDate : 2004-4-15 \\
\hline ArticleHistory & $:$ & OnlineDate \\
\hline \hline ArticleCopyright & $:$ & BioMed Central Ltd2004-4-15 \\
\hline \hline ArticleGrants & $:$ & \\
\hline \hline ArticleContext & $:$ & 130594411 \\
\hline \hline
\end{tabular}


Although the understanding of gene regulation networks and their importance has grown, how these complex pathways evolved has been poorly understood. New research in the April 11 Nature Genetics suggests that during evolution gene duplication and subsequent divergence could have been responsible for up to $90 \%$ of the interactions seen in gene regulatory networks.

Sarah A. Teichmann and M. Madan Babu at the Medical Research Council in Cambridge, UK, looked for homologous genes in known genetic networks in Escherichia coli and Saccharomyces cerevisiae to discover instances of duplication. Teichmann said that their approach to identifying and quantifying effects of duplication was different from previous attempts in that they were looking at both transcription factors and target genes together. They had captured both recent and distant evolutionary relationships by using information about structural domains in homologous genes, using a hidden Markov model database called SUPERFAMILY.

"The general principle behind this is that structure changes more slowly than sequence," Teichmann said. "Things can be conserved at the level of three-dimensional structure, whereas the amino acid sequence can be completely different." By mapping domains of known structure onto transcription factors and their target genes, a much more complete picture of the evolutionary relationships of the entire regulatory network was obtained, she said.

The authors' results indicated that the $90 \%$ observed duplication of gene networking interactions could be further broken down. Simple duplication while retaining the interactions of the ancestor accounts for about $50 \%$ of duplications, and the remaining half of duplication cases involve inventing new interactions relative to their ancestors. "When we say $90 \% \ldots$ we're including those [new interaction] cases, and that's not to be sniffed at either; that occurs fairly frequently as well," Teichmann said.

Teichmann described two recently discovered topological elements involving transcription factors and target genes in network connectivity. In the feed-forward mechanism, two transcription factors act on one target gene. In single-input modules, one transcription factor acts on two target genes - single input because there is only one input of one transcription factor. "Given these building blocks, [we asked whether either of] these structures has been copied as a module, as a whole, within the network," she said. The results show that instead of duplicating whole modules, individual interactions have been created by duplication, and hence each module is built up in a stepwise manner.

"It is as if you were designing a kind of electrical circuit board," said Matthew W. Hahn, from the Department of Evolution and Ecology, University of California at Davis, who was not involved in the study. "If an engineer did it, there would be certain kinds of circuits that were most robust to failure, and... what they're saying is that nature makes the best circuit often."

The same circuits are evolving independently in multiple genomes, Hahn said, but it doesn't seem to be that the whole circuit is kept over time. "You see different genes that are in these same kinds of circuits, but in different organisms. So in E. coli and Saccharomyces, the same kind of feed-forward motifs or single-input modules occur, but with different genes in each of the different genomes," Hahn said. 
John F.Y. Brookfield, from the Institute of Genetics at Nottingham University, said the authors had used quite sophisticated techniques to try and identify genes that were truly homologous, and therefore the result of gene duplication. However, the timing of the duplication events - which could be millions of years apart - had not been considered. "I think it will be interesting to see the extent to which billionyear-old genes and million-year-old genes, to take extreme examples, differ in the extent to which they have different roles in the network," said Brookfield, who was not involved in the study.

\section{References}

1. Nature Genetics, [http://www.nature.com/ng/]

2. Sarah A. Teichmann, [http://www.mrc-lmb.cam.ac.uk/genomes/Sarah/]

3. Design Principles of Protein Networks, Weizmann Institute of Science, [http://www.weizmann.ac.il/ $\mathrm{mcb} /$ UriAlon/]

4. Matthew W. Hahn, [http://www.duke.edu/ mwh3/]

5. John F.Y. Brookfield, [http://www.nottingham.ac.uk/genetics/staff/johnbrookfield/]

This PDF file was created after publication. 